FACTA UNIVERSITATIS

Series: Physical Education and Sport, Vol. 18, No 1, 2020, pp. 249 - 261

https://doi.org/10.22190/FUPES190508022P

Research article

\title{
THE IMPACT OF SPORT GAMES EXERCISE PROGRAMS ON THE DEVELOPMENT OF SPECIFIC MOTOR ABILITIES IN ADOLESCENTS WITH INTELLECTUAL IMPAIRMENT
}

\author{
UDC 796.012.01 \\ 615.01
}

\begin{abstract}
Aleksandar Pejčić ${ }^{1}$, Miodrag Kocić
${ }^{1}$ School for Adult Education Dositej Obradović, Leskovac, Serbia

${ }^{2}$ Faculty of Sport and Physical Education, University of Niš, Niš, Serbia
\end{abstract}

\begin{abstract}
The aim of this study was to determine the effects of a sports games experimental program on improving specific motor abilities in adolescents with mental impairment. The study was conducted on a sample of 60 adolescents diagnosed with mild mental impairment, divided into two groups (experimental group EG, and control group $C G)$ with an equal number of participants. The special program of sports games lasted for 12 weeks, with a weekly frequency of four times and a duration of 30 minutes per training. The participants of both groups were tested with the same variables within the specific motor skills for the sport of football and basketball. After a twelve-week experimental program of sports games, there were statistically significant improvements in the EG in the variables: $S M F S, S M D R, S M C P$ with a statistical significance of $r=0.000$. The results of the ANOVA and MANOVA analyses indicated that after the application of the specific sports games program there was a statistically significant difference in the benefits for the $E G$ compared to the $C G$, in the parameters of specific motor abilities with a statistical significance $r=0.000$ and the size of the impact. Based on these research results, it can be concluded that a specific exercise program conducted within twelve-week training of specifically dosed sports activities has significantly contributed the development of specific motor skills for football and basketball.
\end{abstract}

Key words: Football, Basketball, Mild Mental Impairment, Adolescents

\author{
Received May 8, 2019/ Accepted May 7, 2020 \\ Corresponding author: Aleksandar Pejčić \\ School for Adult Education Dositej Obradović, Vlajkova 24, 16000 Leskovac, Serbia \\ Phone: + $38116215771 •$ E-mail: acapejcic@yahoo.com \\ C 2020 by University of Niš, Serbia | Creative Commons License: CC BY-NC-ND
}




\section{INTRODUCTION}

According to the latest research, the population of people with disabilities worldwide is about $10 \%$, which is about 800 million people (Popović, 2015). This group of people include persons with physical disabilities, persons with sensory disabilities and persons with intellectual disabilities or mental impairment (Đurašković \& Živković, 2009). There are between 120 to 200 million people with intellectual disabilities worldwide (American Association on Mental Retardation, 1992). Such data indicate the necessary seriousness in organizing and implementing, above all, systemic support for their life and work.

Mental retardation defines the condition of an impaired or underdeveloped mind, which can be seen through a characteristic impairment of the abilities that contribute to the development of intelligence: motor skills, speech, thinking and socializing. According to this definition there are levels of mental impairment that are determined by the intelligence coefficient. Those are light mental impairment (intelligence coefficient from 50 to 70), persons developed at the level of a 7 to a 12 year-old, mild mental impairment (intelligence coefficient from 35 to 49), persons developed at the level of a 4 to a 7 year-old, hard mental impairment (intelligence coefficient from 20 to 34), persons developed at the level of a 2 to a 4 year-old, difficult mental impairment (intelligence coefficient below 20), persons developed at the level of a 2 year-old (WHO, 1992; Szymanski \& King, 1999; King, Hodapp, \& Dykens, 2000; Not, 2008).

People with diagnosed intellectual impairment are persons, in the broadest sense, who are not fully able to comply with all the social norms of an average person. There are many definitions of this impairment (WHO, 1992; American Association on Mental Retardation, 1992; Szymanski \& King, 1999).

The physical activity (PA) of this population, and generally people with disabilities nowadays is no longer a taboo, and is rapidly developing and improving in accordance with the needs of certain disability groups (Đurašković \& Živković, 2009). People with diagnosed mental impairment are people whose muscular functionality is preserved, and who have no limitation in the movement amplitudes. However, due to weaker motor skills, their movements, especially more complex movements, are very difficult, i.e., they have no slope of movements during performance. This problem is more pronounced with a smaller intelligence coefficient (King et al., 2000; Not, 2008). Because of this, these persons were from the very beginning of their life, their school age, ignored by persons without disabilities, which emphasized their malaise in the social environment, reducing their desire to take an active part in any kind of PA (Radivojević \& Raičević, 2007). The results of all this were quantified by various studies that dealt with the discovery of the differences between the population diagnosed by mental impairment and the one without it (Graham \& Reid, 2000).

Great differences in physical capacities, fitness components (cardiorespiratory and cardiovascular), as well as in body composition, are present between people with and without disabilities, in favor of people without disabilities. For these reasons, today's environment in which people with diagnosed mental impairment live is an organized system adapted to their personal needs, enabling them to develop their potentials. Today, people with disabilities can be physically active through specialized primary and secondary education, in terms of physical skills through sports associations together with their friends with the same or similar levels of mental impairment (Stanišić, 2013; Popović, 2015). An organized aspect of PA through sports content at international levels is organized within the so-called Special Olympics (Đurašković \& Živković, 2009). At such organized sports gatherings, these people, depending on the level 
of their intellectual abilities, i.e., their coefficient of intelligence, are classified and they compete in various individual and collective sports, with rules adapted to their abilities (Đurašković \& Živković, 2009).

Sports games as organized physical activities represent a very important factor especially in the developmental period of life, adolescence. The maximum utilization of the physical, motor skills, potentials of the person contributes to the preservation and improvement of their health, as well as to the improvement of the quality of their lives. It also affects the development of social components and social integration (Podgorski, Kessler, \& Cacia, 2004; Cowley et al., 2010). Football and basketball as some of the basic collective ball games, with the highest popularity in the world, provide the opportunity to meet all the motor skill needs for people with diagnosed disabilities due to the presence of the following elements: jumping, throwing, running, shooting.

The significance of these sports games is due to a specific organized educational system (Radenković, Berić, \& Kocić, 2014) adapted to this population of people within the hours of physical education organized in the period of intense growth and bodily development, i.e., adolescence (Stanišić, 2013; Popović, 2015). However, the implementation and organization of lectures is not directly classified and adapted to the appropriate levels of mental impairment. Persons diagnosed with mild mental impairment whose level of intelligence ranges from 50 to 70 represent a group of people who, with the help of adequate methods and realization of physical education classes that are time-modified (for a duration of 30 minutes) would be more beneficial than physical education classes for a duration of 45 minutes, which are beneficial for persons without any disabilities (Stanišić, Berić, Bojić, Nurkić, \& Kocić, 2012; Stanišić, Kocić, Aleksandrović, Stanković, \& Radovanović, 2012).

Pursuant to this, special programs of sports games, focused only on the level of mild mental impairment, provide the possibility of developing specific motor skills potential.

Adolescents diagnosed with mental impairment represent a population of children who are different from adolescents who are not diagnosed with mental impairment, firstly at the cognitive characteristics level. Due to the marginalization of this population of people and their very frequent rejection by the environment (due to the increased ability limitation), adolescents with this disability are less physically active and less motivated to deal with any kind of PA. This certainly affects the difference in the level of fitness components; increased levels of fat, that is, obesity is more common with children not diagnosed with mental impairment (Maksimović, 2012).

In terms of motor skills, persons diagnosed with mental impairment have poorer results in almost all motor skills. This difference is specifically expressed in movement coordination (which is considered to be motor intelligence) and whose development and ability can greatly improve the manifestation of other basic and motor skills (Chaiwanichsiri, Sanguanrungsirikul, \& Suwannakul, 2000; Guideti, Franciosi, Gallota, Emeranziani, \& Baldari, 2010; Iveković, 2013).

Specific motor skills are skills that are related to the performance of a movement, element or exercise in sports activities, which combines two or more basic and motor skills, thereby affecting an increased limitation in performance (Stojiljković, 2003, 114). However, people diagnosed with mild mental impairment (70 to 50) have abilities like children aged 9 to 12 who are not diagnosed with intellectual disability (King et al., 2000; Not, 2008).

Adolescents with mild mental impairment while engaging in PA within sports games have to pay more attention, i.e., they need more repetition and more time to master the technical 
elements (Golubović, Maksimović, Golubović, \& Glumbić, 2012). There are also very many unnecessary movements in more complex elements, or in the course of expressing specific motor movements (Hartman, Houwen, Scherder, \& Visscher, 2010; Golubović et al., 2012).

Having in mind the above mentioned, the aim of this study is to determine the effects of a special exercise program on the development of specific motor abilities in sports games in adolescents with diagnosed mental impairment.

\section{METHODS}

\section{Sample of participants}

The study included 60 participants diagnosed with light mental impairment. The participants were adolescents aged 13 to 17 attending higher elementary school grades (grades 5 to 8 ) in the "14. October" elementary school from Niš and the "11 October" secondary school from Leskovac.

The participants were divided into two groups of 30 members each. The adolescents diagnosed with mild mental impairment: the experimental group (EG) had four hours of a special program of sports games aimed at developing motor skills; the control group (CG) had three regular physical education classes and one more lesson of physical education of the chosen sport prescribed by the plan and program of the Ministry of Education, Science and Technological Development of the Republic of Serbia.

Due to the fact that the participants were underage, their guardians consented in providing permission for them to participate in this research.

\section{Sample of measuring instruments}

In the testing of specific motor skills for basketball, the assessment was carried out through four elements: running the ball (SMRB in points), catching the ball (SMCB in points), passing the ball (SMAB in points), and shooting at the basket (SMSB in points). The test battery that was used had been used in previous studies of this population (Guidetti, Franciosi, Emerenziani, Gallotta, \& Baldari, 2009; Stanišić et al., 2012a). To assess the specific motor abilities of the participants, adolescents with diagnosed light mental impairment, specific motor tests for football and basketball were used. Within the framework of specific motor tests for football, assessment tests of three elements were used: shooting at the goal (SMSG in points), dribbling (SMDR in points), controlling and passing the ball (SMCP in points). This group of tests for the assessment of specific motor skills was also applied in the research of Popović (2015). This test was designed to consist of four levels, classified by the weight of the performance of each of these elements, and each level contains five different tasks within each element. Each task carries a maximum of one point if it is successfully done, half a point if the attempt was not properly performed, but there were also zero points if the participant did not attempt to perform the task at all. Each task carries a maximum of one point, each element within a single level carries five points, and each level makes a total of 20 points. If the participant did not achieve a minimum of 15 points within one level, he could not move on to the second level of complexity required to perform elements. 


\section{Experimental program}

The expressive program of sports games lasted for 12 weeks with a weekly frequency of four times a week for 30 minutes. During that time, the participants mastered the technical elements for football (leading the ball, shooting at the goal and passing the ball) and basketball (leading the ball, catching the ball, passing the ball and shooting at the basket) during the main part of the lesson. During each lesson, the participants performed two or more elements by ten repetitions for a warm-up and for raising the muscle tonus that should be activated during the main part of the lesson. The last five minutes were reserved for muscle relaxation and body preparation for further school activities.

\section{Statistical data processing}

Data processing was performed by the SPSS statistics program (v17.0, SPSS Inc., Chicago, IL, USA).

All data were presented descriptively, while in order to determine statistically significant differences at the univariate level, a t-test for independent samples was used.

In order to determine whether there are differences, but primarily which variables contribute to the difference at the final measurement between the EG and CG the most, a canonical descriptive analysis was used.

A multivariate analysis of variance (MANOVA) was used to determine the differences within groups for different measurements. The differences for each measuring instrument or variable were determined by a univariate analysis of variance (ANOVA).

In order to determine the effects of a special sports games program, the neutralization of the differences at the initial measurement between the groups was performed using MANCOVA (a multivariate analysis of covariance) and ANCOVA (a univariate analysis of covariance).

\section{RESULTS}

Table 1 Specific motor abilities: T-test comparison between the EG and the CG at the initial measurement

\begin{tabular}{lrrcrrrr}
\hline $\begin{array}{l}\text { Variables } \\
\text { (in points) }\end{array}$ & $\begin{array}{c}\text { Mean } \\
\text { EG }\end{array}$ & $\begin{array}{c}\text { Mean } \\
\text { CG }\end{array}$ & $\begin{array}{c}\text { Mean Diff } \\
\text { (EG-CG) }\end{array}$ & t & df & p & Cohen's d \\
\hline SMRB & 10.18 & 8.97 & 1.22 & 0.98 & 58 & 0.33 & 0.14 \\
SMCB & 9.02 & 9.15 & -0.13 & -0.11 & 58 & 0.91 & -0.02 \\
SMAB & 7.98 & 8.27 & -0.28 & -0.23 & 58 & 0.82 & -0.03 \\
SMSB & 6.77 & 7.20 & -0.43 & -0.36 & 58 & 0.72 & -0.05 \\
SMSG & 75.67 & 72.67 & 3.00 & 0.48 & 58 & 0.63 & 0.09 \\
SMDR & 43.00 & 38.67 & 4.33 & 1.01 & 58 & 0.31 & 0.18 \\
SMCP & 49.00 & 52.67 & -3.67 & -0.74 & 58 & 0.46 & -0.13 \\
\hline
\end{tabular}

Legend: Mean EG - average value of the results of the experimental group; Mean CG - average value of the results of the control group; Mean Diff (EG-CG) - differences gained when subtracting the arithmetical mean of the experimental group and the arithmetical mean of the control group; $\mathrm{t}$ - calculated value of the $\mathrm{t}$-test; $\mathrm{df}$ - degree of freedom; $\mathrm{p}$ - statistical significance of the $\mathrm{t}$-test Cohen's $\mathrm{d}$ - calculating the Cohen`s indicator of the difference size 
The results shown in table 1 describe the differences between the EG and the CG at the initial measurement within the variables that describe the specific motor space. Based on these results, it can be noticed that there are no statistically significant differences between the EG and the CG at the initial measurement within the specific motor variables.

Table 2 Specific motor abilities: T-test comparison between the EG and CG at the final measurement

\begin{tabular}{lrcccccc}
\hline $\begin{array}{l}\text { Variables } \\
\text { (in points) }\end{array}$ & $\begin{array}{c}\text { Mean } \\
\text { EG }\end{array}$ & $\begin{array}{c}\text { Mean } \\
\text { CG }\end{array}$ & $\begin{array}{c}\text { Mean Diff } \\
\text { (EG-CG) }\end{array}$ & $\mathrm{t}$ & $\mathrm{df}$ & $\mathrm{p}$ & Cohen's d \\
\hline SMRB & 10.90 & 8.85 & 2.05 & 1.64 & 58.00 & 0.11 & $0.24^{*}$ \\
SMCB & 9.90 & 8.72 & 1.18 & 0.98 & 58.00 & 0.33 & 0.14 \\
SMAB & 8.87 & 7.95 & 0.92 & 0.73 & 58.00 & 0.47 & 0.10 \\
SMSB & 7.63 & 6.82 & 0.82 & 0.69 & 58.00 & 0.49 & 0.10 \\
SMSG & 87.67 & 64.33 & 23.33 & 3.62 & 58.00 & $0.00^{* *}$ & $0.65^{* *}$ \\
SMDR & 50.33 & 33.33 & 17.00 & 3.82 & 58.00 & $0.00^{* *}$ & $0.68^{* *}$ \\
SMCP & 59.33 & 43.00 & 16.33 & 3.57 & 58.00 & $0.00^{* *}$ & $0.64^{* *}$ \\
\hline
\end{tabular}

Legend: Mean EG - average value of the results of the experimental group; Mean CG - average value of the results of the control group; Mean Diff (EG-CG) - differences gained when subtracting the arithmetical mean of the experimental group and the arithmetical mean of the control group; $t$ - calculated value of the t-test; $\mathrm{df}$ - degree of freedom; $\mathrm{p}$ - statistical significance of the $\mathrm{t}$-test Cohen's $\mathrm{d}$ - calculating the Cohen`s indicator of the difference size

Based on the results presented in table 2, which describes the differences between the EG and the $\mathrm{CG}$ at the final measurement within the variables of the specific motor space, it can be seen that there is a difference between the EG and CG. This difference can be noticed in the SMFS variable, and is in favor of the EG with a statistical significance of the test $(r=0.00)$ and Cohen's size indicator $d(0.65)$. Differences were also observed in the MGLR variable in favor of the EG with a statistical significance of the test $(r=0.00)$ and Cohen's size indicator d $\left(0.68^{* *}\right)$, in SMCP in favor of the EG with a statistical significance of the test $(\mathrm{r}=0.00)$ and Cohen's size indicator $(0.64 * *)$. In the other variables at the final measurement within the specific motor skills between the EG and the CG, there were no statistically significant differences.

Table 3 Significance of an isolated discriminatory function

\begin{tabular}{cccccc}
\hline Eigen & Canonical R & Wilks' L. & Chi-sqr. & df & $p$ \\
\hline 0.650 & 0.628 & 0.606 & 27.279 & 7 & $0.000 * *$ \\
\hline
\end{tabular}

Legend: Eigen - square of the determination coefficient, Canonical R - canonic correlation coefficient, Wilk's L - Wilk's lambda test, Chi-Sqr - Bartlett's $X_{2}$ test, df - degree of freedom, $\mathrm{p}$ - degree of significance

Table 3 shows the results of an isolated discriminatory function. A statistically significant difference can be noticed at the level of $0.01(\mathrm{p}=0.000)$ between the EG and the CG at the final measurement in the specific motor space. A canonical discriminatory analysis has shown that there is one significant discriminatory function, which is very high and explained with $63 \%$ (Canonical $\mathrm{R}=0.628$ ). It shows that the correlation of the data set, based on the way the discriminatory analysis was carried out, is significant and high. The discriminative strength of the variables expressed through the Wilk's L test (0.606) indicates that the function discriminates the participants correctly. Also, based on the isolated discriminative 
function, it can be seen that the high separation power of these two samples is significant, and this function is significant, since the probability of error is equal to 0 . This indicates that the EG and the CG statistically and significantly differ in the part of specific motor skills.

Table 4 Correlations of variables with a discriminative function

\begin{tabular}{lc}
\hline & Function1 \\
\hline SMDR & 0.622 \\
SMSG & 0.590 \\
SMCP & 0.582 \\
SMRB & 0.267 \\
SMCB & 0.159 \\
SMAB & 0.118 \\
SMSB & 0.113 \\
\hline
\end{tabular}

Function 1 - isolated discriminative function

The results in table 4 indicate the correlation of variables with a discriminative function. The essential difference between the EG and the CG in the specific motor functions is in the variables MGLR (0.622), SMFS (0.590), SMCP (0.582), and significantly less in the other variables.

Table 5 Discriminant function coefficients

\begin{tabular}{lc}
\hline & Function 1 \\
\hline SMRB & 3.456 \\
SMCB & -1.137 \\
SMAB & -1.552 \\
SMSB & -0.906 \\
SMSG & 0.370 \\
SMDR & 0.340 \\
SMCP & 0.198 \\
\hline
\end{tabular}

Function 1 - isolated discriminative function

Table 5 shows the results of the coefficients of a descriptive function, which indicate that the EG at the final measurement is specifically better in the variables of SMRB (3.456), SMCB (-1.137), SMAB (-1.552) and SMSB (-0.906).

Table 6 Group centroids

\begin{tabular}{cc}
\hline & \multicolumn{2}{c}{ Function 1} \\
\hline EG & 0.792 \\
EG - experimental group; $\mathrm{CG}-$ control group
\end{tabular}

Table 6 presents the results of the analysis of the group centroids, which represent the arithmetic means between the EG and the CG. The results indicate their high discrimination ranging from 0.792 for the EG and -0.792 for the control group of participants. 
Table 7 Precision of the a posterior classification

\begin{tabular}{lccc}
\hline Group & Percentage & EG & CG \\
\hline EG & 73.3 & 22 & 8 \\
CG & 76.7 & 7 & 23 \\
\hline Total & 75.0 & 30 & 30 \\
\hline EG - experimental group; CG - control group
\end{tabular}

The results in table 7 represent the efficacy of separating the EG and the CG at the final measurement in the variables for basic motor ability assessment. The percentages show that the discrimination was made with a precision of $75 \%$. It can be seen that 22 participants belong to the EG, and 8 the control group, while 23 participants from the control group belong to their own group, and 7 belong to the opposite group.

Table 8 Multivariate analysis of covariance of specific motor abilities between the experimental and the control group at the final measurement

\begin{tabular}{cccccc}
\hline $\begin{array}{c}\text { Wilks' } \\
\text { Lambda }\end{array}$ & F & df1 & df2 & $p$ & $\begin{array}{c}\text { Partial Eta } \\
\text { Squared }\end{array}$ \\
\hline 0.142 & 38.843 & 7 & 45 & $0.000^{* *}$ & 0.858 \\
\hline $\begin{array}{r}\text { Legend: Wilk's Lambda - Wilk`s Lambda test; } \\
\text { p - significant statistical differences }{ }^{*}<0.05 .\end{array}{ }^{* *}<0.0$; Partial Eta Squared - influence size
\end{tabular}

Table 8 shows the results of the multivariate analysis of covariance of the applied variables for the assessment of specific motor abilities between the EG and the CG at the final measurement, neutralizing the recorded differences at the initial measurement. Based on the obtained results, it can be concluded that there is a statistically significant difference at the multivariate level between the EG and the CG, at the significance level of 0.01 (plevel $=0.000$ ). The recorded difference occurs under the influence of the applied experimental program, and it can be concluded that it affects the transformation of specific motor abilities in the experimental group.

Table 9 Univariant analysis of covariance of specific motor abilities between the EG and the $\mathrm{CG}$ at the final measurement.

\begin{tabular}{lcccccc}
\hline $\begin{array}{l}\text { Variables } \\
\text { (in points) }\end{array}$ & $\begin{array}{c}\text { Adj. Mean } \\
\text { EG }\end{array}$ & $\begin{array}{c}\text { Adj. Mean } \\
\text { CG }\end{array}$ & $\begin{array}{c}\text { Adj. Mean } \\
\text { diff.(EG-CG) }\end{array}$ & F & p & $\begin{array}{c}\text { Partial } \\
\text { Eta Squared }\end{array}$ \\
\hline SMRB & 10.19 & 9.56 & 0.63 & 9.03 & $0.004^{* *}$ & $0.15^{* * *}$ \\
SMCB & 9.71 & 8.90 & 0.81 & 14.99 & $0.000^{* *}$ & $0.23^{* * *}$ \\
SMAB & 8.90 & 7.92 & 0.99 & 14.95 & $0.000^{* *}$ & $0.23^{* * *}$ \\
SMSB & 7.80 & 6.65 & 1.15 & 23.97 & $0.000^{* *}$ & $0.32^{* * *}$ \\
SMSG & 88.93 & 63.07 & 25.86 & 83.80 & $0.000^{* *}$ & $0.62^{* * *}$ \\
SMDR & 48.27 & 35.40 & 12.87 & 80.50 & $0.000^{* *}$ & $0.61^{* * *}$ \\
SMCP & 61.76 & 40.57 & 21.19 & 54.78 & $0.000^{* *}$ & $0.52^{* * *}$ \\
\hline
\end{tabular}

Legend: Adj. Mean - corrected arithmetic mean ( $\mathrm{E}$ - experimental group, $\mathrm{K}$ - control group); Adj. Mean diff. - differences between the corrected arithmetic means; F - $\Phi$ test; $p$ - degree of significance, statistically significant difference ${ }^{* *}<0,01{ }^{*}<0,05$; Partial Eta Squared - size of influence $\left(\right.$ small $^{*}$, medium $^{* *}$, high $^{* * *}$ ) 
The results in table 9 show the univariate difference in the variables for the assessment of specific motor abilities between the EG and the CG at the final measurement with the neutralization and partialization of the results at the initial measurement. A statistically significant difference in all variables of this area was determined at the level of significance $r=0.01$.

\section{DISCUSSION}

A special program of sports games is a program within which the participants of the EG mastered and performed the elements of football and basketball. These sports games were an instrument used to influence the development of specific motor skills of the adolescent participants diagnosed with light mental impairment. The results of the initial descriptive statistics proved to be an extremely heterogeneous set of variables for the EG, and also the heterogeneity data were similar to the control group. In accordance with the obtained results from the initial measurement in the factor of heterogeneity, the variables of the specific motor space were also obtained in previous studies (Stanišić et al., 2012a; Stanišić, 2013).

By comparing the results of the initial measurement between the EG and the CG in the variables of specific motor skills, in football and basketball, we did not find significant statistical differences. The obtained results indicate the same starting points in the specific motor skill of the respondents in both sports games, i.e., the participants had similar previous experiences and skills.

The results of the descriptive statistics at the final measurement within the variables describing the condition of the specific motor space of the EG who took part in a special sports games program show an increase in the results. The mean values of the variables determined by the specific motor skills within the game of football increased in all variables: SMFS (Final Measurement Mean=87.67; SD=24.45; Initial Measurement Mean=75.67; $\mathrm{SD}=23.88$ ), SMDR (Final Measurement Mean=50.33; $\mathrm{SD}=16.61$; Initial Measurement Mean=43.00; SD=16.66), SMCP (Final Measurement Mean=59.33; SD=19.11; Initial Measurement Mean=49.00; $\mathrm{SD}=20.23$ ). The obtained results within the descriptive statistics indicate the positive impact of a specific exercise program in the variables of football. Also, the results of the mean values of the variables or tests determining the specific motor abilities after the application of the specific basketball exercise program resulted in an increase in mean values: SMRB (Final Measurement Mean=10.90; SD=5.33; Initial Measurement Mean=10.18; SD=5.17), SMCB (Final Measurement Mean=9.90; SD=5.03; Initial Measurement Mean=9.02; SD=4.68), SMAB (Final Measurement Mean=8.87; SD=5.10; Initial Measurement Mean=7.98; SD=4.89), SMSB (Final Measurement Mean=7.63; $\mathrm{SD}=4.47$; Initial Measurement Mean=6.77; $\mathrm{SD}=4.29$ ).

Positive changes in the results of the descriptive statistics within the mean values indicate that a specific program of sports games with a duration of 12 weeks was beneficial i.e. appropriate. By comparing these results with the results of previous researchers or their research, one can notice the positive statistical contribution of the program with quantum higher values and with a reduction in the duration and the frequency of training (Franciosi, Guidetti, Gallotta, Emerenzian, and \& Baldari, 2010; Stanišić, 2013). Also, due to quantified data representations, it can be noticed that there has been a quantum increase in the mean values in the final measurement results in variables that were evaluated for specific motor 
skills within the game of football. The explanation of these results can be noticed by the specificity of the tests, i.e. by their complexity and the manner of quantifying the skills displayed, but also by the popularization of the game.

For the control group of participants who did not take part in the special sports games program, but who had regular physical education classes prescribed by the plan and program of the Ministry of Education, Science and Technological Development of the Republic of Serbia, the results of descriptive statistics have shown that within the variables that were used to evaluate specific motor skills in the game of football, a slight decrease in the mean values was noted: SMFS (Final Measurement Mean=64.33; SD=25.42; Initial Measurement Mean=72.67; SD=24.06), SMDR (Final Measurement Mean=33.33; SD=17.88; Initial Measurement Mean=38.47; SD=18.2 4), SMCP (Final Measurement Mean=43; SD=16.22; Initial Measurement Mean=52.67; SD=17.99). Also, the results in the variables evaluating the specific motor skills in basketball showed a slight decrease in mean values: SMRB (Final Measurement Mean=8.85; SD=4.31; Initial Measurement Mean=8.97; SD=4.44), SMCB (final measurement Mean=8.72; $\mathrm{SD}=4.32$; Initial Measurement Mean=9.15; $\mathrm{SD}=4.55$ ), SMAB (Final Measurement Mean=7.95; $\mathrm{SD}=4.65$; Initial Measurement Mean=8.27; $\mathrm{SD}=4.70$ ), $\mathrm{SMSB}$ (final measurement Mean=6.82; $\mathrm{SD}=4.65$; Initial Measurement Mean=7.20; $\mathrm{SD}=4.90)$.

Analyzing the results and comparing or noting the existence of differences in the variables of the specific motor skills for football and basketball at the initial measurement between the EG and the CG showed no statistically significant difference in any variables. In accordance with the results, it can be concluded that the existence of knowledge and skills of the participants of both groups was equal. The level of knowledge and skills related to specific motor variables indicate very similar starting points that were a very important parameter for rendering the program's relevance more visible, or obtaining more accurate post-treatment results.

The results of the final measurement of both groups of participants calculated by the $t$ test, which was performed to detect quantifiable differences in the results of specific motor abilities in football and basketball, showed the existence of statistical differences in favor of the EG. A statistically significant high difference was first of all seen in all variables of the specific motor skills for football $(\mathrm{p}=0.00)$. In the variables for the specific motor skills for basketball, the results of the t-test did not show a statistically significant difference. The size of the differences in variables were shown as statistically significantly different (Cohen's d), as the size of the difference was very high. Pursuant to the obtained values, it can be pointed out that football has provided a greater increase in the test results evaluated against basketball, whose results were quantifiably higher than the initial results, but did not have a statistically significant difference as determined by the t-test. However, a slight difference was confirmed by Cohen's d test, and Cohen's indicator of the size of the difference, which established a very low existence of differences.

The canonical descriptive analysis at the final measurement of the variables that indicate the level of the state of the specific motor skills within the game of football and basketball has identified qualitative differences. Differences determined by this statistical analysis showed very high values, i.e. statistical significance $(r=0.001)$. Also, the results which indicate a correlation of variables with a discriminative function indicate an extremely large difference in the variables that determine specific motor skills within the game of football. However, the coefficients of the discriminant function show significant 
improvement and variables that determine the state of specific motor skills in the game of basketball. The results obtained thus in the final measurement indicate that the specific program of sports games for a duration of 12 weeks, with a frequency of four times a week and lasting 30 minutes per training, is sufficient to improve the state of specific motor skills statistically and significantly. Similar studies have also shown an increase in the results in the specific motor space of people with mental impairment (Guidetti et al., 2009; Franciosi, Guidetti, Gallotta, Emerenziani, \& Baldari, 2010; Stanišić, 2013).

The statistical procedures of the ANCOVA and MANCOVA analyses that were applied in the area of specific motor abilities of the participants confirmed the quantitative and qualitative results obtained by descriptive parameters as well as the t-test and canonical correlation analysis. The results of these analyses determined a statistically significant effect on the EG diagnosed with light mental impairment at the adolescent age in all variables used to describe the condition of a specific motor space, with a significance level $r=0.000$. The size of the impact for each individual variable (Partial Eta Squared) was large. The results obtained after the application of this program indicate the quality of the program itself as well as the benefits of the program in accordance with the sample of participants in terms of age characteristics and their abilities. It was easy to see the results of the applied special program for sports games, and the instruments used to determine the specific motor skills that were used in previous studies (Guidetti et al., 2009; Franciosi et al., 2010; Giagazoglou, Arabatzi, Dipla, Liga, \& Kellis, 2012; Blomqvist, Olsson, Wallin, Wester, \& Rehn, 2013; Stanišić, 2013). Also, the research published in the previous ten years suggests that a 12 to 20-week exercise program with a frequency of three to four times a week with a duration of 30 to 40 minutes is sufficient to allow changes in the specific motor skills for the mentioned sports games.

The comprehensiveness of the development of both the basic motor space and the specific motor space within the sport games of football and basketball for adolescent participants diagnosed light mental impairment of both sexes indicates that a specific and specially designed program of sports games was in accordance with the tendencies of solving the research problem. Based on this, it was concluded that the objectives and hypotheses of the research are consistent with the results achieved and are fully accepted.

\section{CONCLUSION}

The twelve-week training program led to statistically significant high changes in specific motor skills in all the variables related to football, as well as in the variables related to basketball, especially in ball control activities. In other variables, envisaged by this research, there is a statistically significant improvement, but with a lower degree of significance.

The results of the current study indicate that a specific exercise program conducted as part of a 12-week training with specifically dosed sports activities has significantly contributed to the development of specific motor skills in the games of football and basketball.

The findings from this research can be of great importance for the development of appropriate models of programs for the development of the abilities of specific motor skills for adolescents diagnosed light mental impairment. It is in the adolescent period, 
when the body is ready to endure the biggest changes during its development, the advantages of this program should be used in the best possible way.

\section{REFERENCES}

American Association on Mental Retardation (1992). Mental Retardation: Definition, classification, and systems of support. 9th ed. Washington, DC: AAMR.

Blomqvist, S., Olsson, J., Wallin, L., Wester, A., \& Rehn, B. (2013). Adolescents with intellectual disability have reduced postural balance and muscle performance in trunk and lower limbs compared to peers without intellectual disability. Research in Developmental Disabilities, 34(1), 198-206.

Chaiwanichsiri, D., Sanguanrungsirikul, S., \& Suwannakul, W. (2000). Poor physical fitness of adolescents with mental retardation at Rajanukul school Bangkok. Journal of the Medical Association of Thailand, 83(11), 1387-1392.

Cowley, PM, Ploutz-Snyder, LL, Baynard, T., Heffernan, K., Jae, SY, Hsu, S., et al. (2010). Physical fitness predicts functional tasks in individuals with Down syndrome. Medicine and Science in Sports and Medicine, 42(2), 388-393.

Đurašković, R., \& Živković, D. (2009). Sport osoba sa posebnim potrebama (Sport for people with special needs). Niš: Faculty of Sport and Physical Education, University of Niš. In Serbian

Franciosi, E., Guidetti, L., Gallotta. M.C., Emerenziani, G.P., \& Baldari, C. (2010). Contributions of selected fundamental factors to basketball performance in adult players with mental retardation. Journal of Strength and Conditioning Research, 24(8), 2166-2171.

Giagazoglou, P., Arabatzi, F., Dipla, K., Liga, M., \& Kellis, E. (2012). Effect of a hippotherapy intervention program on static balance and strength in adolescents with intellectual disabilities. Research in Developmental Disabilities, 33(6), 2265-2270.

Golubović, Š., Maksimović, J., Golubović, B., \& Glumbić, N. (2012). Effect of exercise on physical fitness in children with intellectual disability. Research in Developmental Disabilities, 33(2), 608-614.

Graham, A., \& Reid, G. (2000). Physical fitness of adults with intellectual disability: a 13-year follow-up study. Research Quarterly for Exercise and Sport, 71(2), 152-161.

Guidetti, L., Franciosi, E., Emerenziani, G.P., Gallotta, M.C., \& Baldari, C. (2009). Assessing basketball ability in players with mental retardation. British Journal of Sports Medicine, 43(3), 208-212.

Guideti, L., Franciosi, E., Gallota, M.C., Emeranziani, G.P., \& Baldari, C. (2010). Could sport specialization influence fitness and health of adults with mental retardation? Research in Developmental Disabilities, 31(5), 1070-1075.

Hartman, E., Houwen, S., Scherder, E., \& Visscher, C. (2010). On the relationship between motor performance and executive functioning in children with intellectual disabilities. Journal of Intellectual Disability Research, 54(5), 468-477.

Iveković, I. (2013). The influence of motor planning, coordination and successive abilities on motor development and social behavior of children with developmental disabilities. Croatian Sports Medical News, 28, 99-107.

King, B.H., Hodapp, R.M., \& Dykens, E.M. (2000). Mental retardation. In: H.I. Kaplan, \& B.J. Sadock (Eds). Comprehensive textbook of psychiatry. Philadelphia: Lippincott Williams \& Wilkins.

Maksimovic, J.M. (2012). Students with special needs and physical education. Proceedings of the Teacher Training Faculty, 14, 311-318.

Not, R. (2008). Mental retardation: definition, classification and consistent support for people with intellectual disabilities. New Presence, 4(3), 339-351.

Podgorski, C.A., Kessler, K., \& Cacia, B. (2004). Physical activity intervention for older people with intellectual disability: Report on a pilot project. American Journal on Mental Retardation, 42(4), 272-283.

Popović, M. (2015). Razlike u nivou motoričkih, kognitivnih, konativnih dimenzija i društvenog statusa sportista $i$ saradnika $i$ njihov uticaj na performanse u fudbalskoj utakmici (Differences in the level of motor, cognitive, conative dimensions and social status of athletes and associates and their impact on performance in a football game). Doctoral dissertation, Faculty of Sport and Physical Education, University of Priština. In Serbian

Radivojević, Z., \& Raičević, N. (2007). International protection of persons with mental disabilities. Temida, 10(3), 11-24.

Radenković, M., Berić, D., \& Kocić, M. (2014). The influence of the elements of basketball on the development of motor skills in children with special needs. Facta Universitatis Series Physical Education and Sport, 12(2), 123-130. 
Stanišić, Z., Berić, D., Bojić, I., Nurkić, M., \& Kocić, M. (2012a). The effects of a specially adapted basketball training program in adolescents with mental retardation: a pilot study. Serbian Journal of Sports Sciences, 6(3), 55-70.

Stanišić, Z., Kocić, M., Aleksandrović, M., Stanković, N., \& Radovanović, D. (2012b). The effects of an adapted basketball training program on physical fitness of adolescents with mental retardation: a pilot study. Journal of Experimental and Clinical Research, 13(3), 103-107.

Stanišić, Z. (2013). Efekti treninga adaptivne košarke na specifično motoričke i funkcionalne sposobnosti adolescenata sa mentalnom retardacijom (The effects of adaptive basketball training on specific motor and functional abilities of adolescents with mental retardation). Unpublished doctoral dissertation. Niš: Faculty of Sport and Physical Education, University of Niš. In Serbian

Stojiljković, S. (2003). Osnove opšte antropomotorike (The basics of general anthropomotorics. Niš): Studentski kulturni centar. In Serbian

World Health Organization-WHO (1992). Klasifikacija mentalnih poremećaja i poremećaja ponašanja (Classification of mental disorders and behavioral disorders). Belgrade: Zavod za udžbenike i nastavna sredstva. In Serbian

Szymanski, A., \& King, B. (1999). Practice parameters for the assessment and treatment of children, adolescents, and adults with mental retardation and comorbid mental disorders. Journal of the American Academy of Child \& Adolescent Psychiatry, 38(12), 5S-31S.

\section{EFEKTI SPECIJALNOG PROGRAMA VEŽBANJA NA RAZVOJ SPECIFIČNO MOTORIČKIH SPOSOBNOSTI U SPORTSKIM IGRAMA KOD ADOLESCENATA SA MENTALNOM RETARDACIJOM}

Cilj ovog istraživanja bio je da se utvrde efekti eksperimentalnog programa sportskih igara na poboljšanje specifično motoričkih sposobnosti adolescenata sa mentalnom retardacijom. Istraživanje je sprovedeno na uzorku od 60 ispitanika adolescenata sa dijagnostikovanom lakom mentalnom retardacijom podeljenih u dve grupe, sa jednakim brojem ispitanika. Specijalni program sportskih igara trajao je 12 nedelja, sa nedeljnom učestalošću od četiri puta i dužinom trajanja jedne trenažne jedinice od 30 min. Ispitanici obe grupe su testirani istim varijablama u okviru specifično motoričkih sposobnosti u okviru sportske igre fudbal i sportske igre košarka. Nakon dvanestonedeljnog eksperimentalnog programa sportskih igara došlo je do statistički značajnih poboljšanja kod eksperimentalne grupe u varijablama: SMSG, SMDR, SMCP sa statističkom značajnošću $r=0.000$. Rezultati ANOVA i MANOVA analiza su ukazali da nakon primene specifičnog programa sportskih igara postoji statistički značajna pozitivna razlika u korist eksperimnetalne grupe u odnosu na kontrolnu grupu u parametrima specifično motoričkih sposobnosti sa statističkom značajnošću $r=0.000$ i veličinom uticaja. Na osnovu ovakvih rezultata istraživanja može se zaključiti da specifični program vežbanja sproveden u okviru dvanaestonedeljnih časova specijalno doziranih sportskih aktivnosti je značajno doprineo razvoju specifično motoričkih sposobnosti u okviru sportke igre fudbala i košarke.

Ključne reči: fudbal, košarka, laka mentalna retardacija, adolescenti 